\title{
PENGATURAN PENYUSUNAN PROYEK PERUBAHAN (PROPER) PENDIDIKAN DAN PELATIHAN KEPEMIMPINAN (DIKLATPIM) (STUDI KASUS PENYUSUNAN PROPER DIKLATPIM III dan IV DI DAERAH PROVINSI)
}

\section{Arrangement Of Proper Changes In Education And Training Of Leadership (Diklatpim) (Case Study For Proper Development Of Diklatpim III and IV In The Province Area)}

Syahrin Daulay

Widyaiswara Ahli Utama

Badan Pengembangan Sumber Daya Manusia

Provinsi Kalimantan Tengah Jalan Ade Irma Suryani Nasution Nomor 2 Palangka Raya

*email:

Syahrindaulay16@gmail.com

\section{Kata Kunci:}

Kepemimpinan pendidikan dan pelatihan proyek perubahan,

PNS,

dokumen perencanaan dan penganggaran.

\section{Keywords:}

leadership educational and training project of change,

civil servants,

planning and budgetting document.

\begin{abstract}
Abstrak
Untuk mencapai tujuan nasional diperlukan aparatur sipil negara (ASN) profesional, bebas dari intervensi politik, bersih dari praktik korupsi, kolusi dan nepotisme $(K K N)$, penyelenggara pelayanan publik, perekat dan pemersatu bangsa. Guna mewujudkan ASN dengan kompetensi tersebut, salah satu upaya yang dilakukan adalah mengembangkan kompetensi PNS melalui pendidikan dan pelatihan kepemimpinan (diklatpim). Lembaga Administrasi Negara RI (LAN RI) telah mengeluarkan pedoman penyelenggaraan diklatpim tingkat IV dan tingkat III melalui Peraturan Kepala LAN RI (Perkalan) masing-masing Nomor 19 Tahun 2015 dan Nomor 20 Tahun 2015.
\end{abstract}

Peserta diklatpim harus mampu merancang perubahan isu strategis nasional, daerah/wilayah sekaligus memimpin perubahan guna mencapai hasil signifikan. Kompetensi yang dibangun adalah kepemimpinan visioner yang mampu berkolaborasi dengan pemangku kepentingan strategis untuk menangani isu strategis nasional guna mencapai tujuan nasional yang efektif dan efisien.

Sampai Juni 2018 jumlah alumni diklatpim tingkat IV dan tingkat III Provinsi Kalimantan Tengah mencapai 1.400 orang dengan total proper sebanyak 1.400 buah. Dari jumlah tersebut yang mendaftar pada Sinopadik dan JIK hanya 12 orang. Minimnya pendaftar karena para alumni sudah beralih jabatan, proper tidak terakomodir dalam dokumen perencanaan dan penganggaran (PP), tidak masuk ranking 10 terbaik, serta tidak menjawab.

\begin{abstract}
In order to achieve national goals, it is required civil servant which are professional, free from political intervention, corruption, collusion and nepotism, functioned as public services, adhesive and unifying nation. One of the efforts that must be made to realize such competencies, is civil servant must take part leadership educational and training (diklatpim). National Institute for Public Administration of the Republic of Indonesia (NIPA) or LAN RI has releaseddiklatpim regulation level III and level IV through Regulation of The Head of NIPA RI Number 19 Year 2015 and Number 20 Year 2015 respectively.
\end{abstract}

Diklatpim participants must be able to design the change of strategic issues of national, regional, and at the same time to lead the change in order to achieve significant output. The competence that must be built is visioner leadership that able to cooperate with other strategic stakeholders to manage those national strategic issues to achieve national goals effectively and efficiently.

Up to June 2018, the total number of alumni of diklatpim both level IV and level III in Central Kalimantan Province was I,400 participants, meaning that the number of the project of change ( $\mathrm{PoC}$ ) also was I,400 projects. However the number of alumni that enrolled to participate in innovation competition after diklatpim(sinopadik) and Kalimantan Innovation Jamboree (IIK) 2018 was only 12 participants from the province. The reason for the small number of alumni to enroll in those competitions amongst others were mutations, the selected issues were not accommodated in the planning and budgetting (PB) documents, and not in the best ten of the rank.

\section{Accepted}

September 2019

Published

December 2019 


\section{PENDAHULUAN}

\section{I. Latar Belakang}

\begin{tabular}{llllr} 
Untuk & \multicolumn{1}{c}{ mencapai } & \multicolumn{2}{c}{ tujuan nasional } \\
sebagaimana tertuang pada & Alinea & ke-4 \\
Pembukaan & Undang-Undang & Dasar & Negara \\
Republik Indonesia Tahun I945 (UUD 1945) \\
diperlukan aparatur sipil negara (ASN) yang \\
profesional, bebas dari intervensi politik, bersih
\end{tabular}
dari praktik korupsi, kolusi dan nepotisme (KKN), mampu menyelenggarakan pelayanan publik bagi masyarakat dan berperan sebagai perekat dan pemersatu bangsa berdasarkan Pancasila dan UUD 1945. Tujuan nasional sebagaimana diamanatkan dalam Pembukaan UUD 1945 adalah melindungi segenap bangsa Indonesia dan seluruh tumpah darah Indonesia, memajukan kesejahteraan umum, mencerdaskan kehidupan bangsa, dan ikut melaksanakan ketertiban dunia yang berdasarkan kemerdekaan, perdamaian abadi dan keadilan sosial.

Untuk mewujudkan tujuan nasional tersebut diperlukan Pegawai ASN yang diserahi tanggung jawab melaksanakan tugas pelayanan publik, tugas pemerintahan dan tugas pemerintahan tertentu. Untuk melaksanakan tugas-tugas tersebut Pegawai ASN harus memiliki profesi dan manajemen ASN yang didasarkan pada sistem merit. Sistem merit adalah perbandingan antara kualifikasi, kompetensi, dan kinerja yang dipersyaratkan oleh jabatan dengan kualifikasi, kompetensi dan kinerja yang dimiliki oleh calon dalam rekrutmen, pengangkatan, penempatan dan promosi pada jabatan dilaksanakan secara terbuka sejalan dengan tata kelola pemerintahan yang baik (good governance)

Melihat luasnya wilayah Negara Kesatuan Republik Indonesia (NKRI) dan panjangnya rentang kendali dalam pemberian pelayanan publik maka salah satu upaya dan strategi agar pelayanan publik berjalan efektif dan efisien dalam sistem NKRI adalah pemberian tugas dan wewenang kepada pemerintahan daerah sebagaimana diamanatkan dalam Undang-Undang RI Nomor 23 Tahun 2014 Tentang Pemerintahan Daerah (UU PD). Dalam UU PD tersebut daerah diberikan kewenangan mengatur dan mengurus sendiri urusan pemerintahan menurut asas otonomi dan tugas pembantuan. Dengan pemberian kewenangan tersebut diharapkan pelayanan publik di daerah akan meningkat secara signifikan yakni lebih responsif, lebih partisipatoris, lebih transparan dan lebih akuntabel. Namun kenyataannya pelayanan publik dimaksud belum berjalan sebagaimana mestinya. Hal tersebut umumnya akibat kurangnya kompetensi birokrat penyelenggara pelayanan publik sebagaimana yang diharapkan (Silalahi dan Wirman, 20I5).

\section{TINJAUAN PUSTAKA}

\section{I Landasan Teori}

\section{I.I Pelayanan Publik}

Pemerintah milik masyarakat akan tercipta jika pemerintah dapat mendefinisikan ulang tugas dan fungsi mereka. Patut diduga bahwa banyak pemerintah yang dalam hal ini para birokrat tidak memahami secara pasti atau setidaknya tidak mengerti filosofi pelayanan yang akan diberikan sehingga pelayanan publik yang dimimpikan oleh masyarakat jauh dari kenyataan yang mereka alami.

Untuk menelaah pelayanan publik secara konseptual, perlu dibahas pengertian kata demi kata. Menurut Kotler dalam Sampara Lukman seperti disadur oleh Juniarto dan Sidik 2017, pelayanan adalah setiap kegiatan yang menguntungkan dalam suatu kumpulan atau kesatuan, dan menawarkan kepuasan meskipun hasilnya tidak terikat pada suatu produk secara fisik. Selanjutnya menurut Sampara seperti disitir oleh Juniarto dan Sidik 2017, pelayanan adalah suatu kegiatan atau urutan kegiatan yang terjadi dalam interaksi langsung antar seseorang dengan 
orang lain atau mesin secara fisik, dan menyediakan kepuasan pelanggan. Sementara dalam Kamus Bahasa Indonesia dijelaskan pelayanan adalah hal, cara, atau hasil pekerjaan yang melayani. Sedangkan melayani adalah menyuguhi (orang) dengan makanan atau minuman; menyediakan keperluan orang; menyajikan; menerima; menggunakan.

Sementara itu kata publik berasal dari bahasa Inggris Public yang berarti umum, masyarakat, negara. Kata publik sebenarnya sudah diterima manjadi bahasa Indonesia baku, pengertiannya adalah orang banyak. Sementara itu Inu Kencana dalam Juniarto dan Sidik (2017) mendefinisikan publik adalah sejumlah manusia yang memiliki kebersamaan berpikir, perasaan, harapan, sikap, dan tindakan yang benar dan baik berdasarkan nilai-nilai norma yang ada. Oleh karena itu pelayanan publik diartikan sebagai setiap kegiatan yang dilakukan oleh pemerintah terhadap sejumlah manusia yang memiliki kegiatan yang menguntungkan dalam suatu kumpulan atau kesatuan, dan menawarkan kepuasan meskipun hasilnya tidak terkait pada suatu produk secara fisik.

Sementara itu Juniarto dan Sidik (2017) sendiri berpendapat bahwa yang dimaksud dengan pelayanan publik adalah pelayanan yang diberikan oleh pemerintah sebagai penyelenggara negara terhadap masyarakat guna memenuhi kebutuhan dari masyarakat itu sendiri dan memiliki tujuan untuk meningkatkan kesejahteraan masyarakat.

Sementara itu menurut Ketetapan Menteri Perdayagunaan Aparatur Negara No.63/KEP/M.PAN/7/2003, pelayanan publik adalah segala kegiatan pelayanan yang dilaksanakan oleh penyelenggara pelayanan publik sebagai upaya memenuhi kebutuhan penerima pelayanan maupun pelaksanaan ketentuan peraturan perundang- undangan. Untuk lebih jelas, pelayanan publik ini dibagi dalam kelompok-kelompok:

a. Kelompok Pelayanan Administratif, yaitu pelayanan yang menghasilkan berbagai bentuk dokumen resmi yang dibutuhkan oleh publik, misalnya status kewarganegaraan, sertifikat kompetensi, kepemilikan atau penguasaan terhadap suatu barang dan sebagainya. Dokumen-dokumen ini antara lain Kartu Tanda Penduduk (KTP), Akte Pernikahan, Akte Kelahiran, Akte Kematian, Buku Pemilik Kendaraan Bermotor (BPKB) Surat Izin Mengemudi (SIM), Surat Tanda Nomor Kendaraan Bermotor (STNK), Izin Mendirikan Bangunan (IMB), Paspor, Sertifikat Kepemilikan/Penguasaan Tanah dan sebagainya;

b. Kelompok pelayanan barang, yaitu pelayanan yang menghasilkan berbagai bentuk/jenis barang yang digunakan oleh publik, misalnya jaringan telepon, penyediaan tenaga listrik, air bersih dan sebagainya;

c. Kelompok pelayanan jasa, yaitu pelayanan yang menghasilkan berbagai bentuk jasa yang dibutuhkan oleh publik, misalnya pendidikan, pemeliharaan kesehatan, penyelenggaraan transportasi, pos, dan sebagainya.

Dengan demikian pelayanan publik adalah pemenuhan keinginan dan kebutuhan masyarakat oleh penyelenggara negara, dalam hal ini negara didirikan oleh publik (masyarakat) tentu saja dengan tujuan agar dapat meningkatkan kesejahteraan masyarakat. Pada hakikatnya negara dalam hal ini pemerintah (birokrat) haruslah dapat memenuhi kebutuhan masyarakat. Kebutuhan ini harus dipahami bukanlah kebutuhan secara individual akan tetapi berbagai kebutuhan yang sesungguhnya diharapkan oleh masyarakat. 
Secara teoritis, tujuan dari pelayanan publik pada dasarnya adalah memuaskan masyarakat. Untuk mencapai kepuasan itu dituntut kualitas pelayanan prima yang tercermin dari:

a. Transparansi, yakni pelayanan yang bersifat terbuka, mudah, dan dapat diakses oleh semua pihak yang membutuhkan serta disediakan secara memadai serta mudah dimengerti;

b. Akuntabilitas, yakni pelayanan yang dapat dipertanggung jawabkan sesuai dengan ketentuan peraturan perundang-undangan;

c. Kondisional, yakni pelayanan yang sesuai dengan kondisi dan kemampuan pemberi dan penerima pelayanan dengan tetap berpegang pada prinsip efisiensi dan efektivitas;

d. Partisipatif, yakni pelayanan yang dapat mendorong peran serta masyarakat dalam penyelenggaraan pelayanan publik dengan memperhatikan aspirasi, kebutuhan dan harapan masyarakat;

e. Kesamaan hak, pelayanan yang tidak melakukan diskriminasi dilihat dari aspek apapun khususnya suku, ras, agama, golongan, status sosial, dan lain-lain.

f. Keseimbangan hak dan kewajiban, yakni pelayanan yang mempertimbangkan aspek keadilan antara pemberi dan penerima pelayanan publik.

\section{I.2 Perencanaan dan Penganggaran \\ Pemerintahan Daerah Provinsi \\ Dalam Undang-Undang RI Nomor 25 Tahun} 2004 Tentang Sistem Perencanaan Pembangunan Nasional (UU SPPN) disebutkan bahwa SPPN adalah satu kesatuan tata cara perencanaan pembangunan nasional untuk menghasilkan rencana pembangunan dalam jangka panjang, jangka menengah dan tahunan yang dilaksanakan unsur penyelenggara pemerintahan di pusat dan daerah dengan melibatkan masyarakat.Seterusnya dalam Undang-Undang RI Nomor 23 Tahun 2014 tentang Pemerintahan Daerah (UU PD) khususnya Bagian Kedua Perencanaan Pembangunan Daerah disebutkan bahwa Pemerintah Daerah sesuai kewenangannya menyusun rencana pembangunan daerah sebagai satu kesatuan dalam SPPN, yang dikordinasikan, disinerjikan dan diharmonisasikan oleh Perangkat Daerah terkait dengan pendekatan politis, teknokratik, partisipatif, bawah-atas dan atas-bawah.

Dokumen perencanaan pembangunan daerah terdiri dari RPJPD, RPJMD dan RKPD. RPJPD disusun dengan berpedoman kepada RPJPN dan tata ruang wilayah. RPJMD disusun dengan berpedoman kepada RPJPD dan RPJMN. RKPD merupakan penjabaran dari RPJMD yang memuat rencana kerangka ekonomi daerah, prioritas pembangunan daerah serta rencana kerja dan pedanaan untuk jangka waktu satu tahun yang disusun dengan berpedoman kepada RKP dan program strategis nasional yang ditetapkan pemerintah pusat.

Terdapat lima pendekatan dalam seluruh rangkaian proses perencanaan dalam Sistem Perencanaan Pembangunan Nasional sebagaimana diamanatkan Undang-Undang Nomor 25 Tahun 2004 yakni pendekatan: politik, teknokratik, partisipatif, atas bawah (top-down), dan bawah atas (bottom-up). Pendekatan politik memandang bahwa pemilihan kepala daerah (pilkada) adalah tahap awal dari proses penyusunan rencana, karena rakyat pemilih menentukan pilihannya berdasarkan program-program pembangunan yang ditawarkan/dijanjikan oleh masing-masing pasangan calon (paslon) kepala daerah. Dalam pandangan seorang perencana, Pilkada pada dasarnya adalah proses pemilihan/penentuan “RPJMD”. Oleh karena itu, rencana pembangunan adalah penjabaran dari agenda-agenda 
pembangunan yang ditawarkan/dijanjikan paslon kepala daerah pada saat kampanye ke dalam rencana pembangunan jangka menengah (RPJMD).

RPJMD merupakan penjabaran dari visi, dan program kepala daerah yang memuat tujuan, sasaran, strategi, arah kebijakan, Pembangunan Daerah, dan Keuangan Daerah, serta program Perangkat Daerah dan Lintas Perangkat Daerah yang disertai dengan kerangka pendanaan bersifat indikatif untuk jangka waktu 5 (lima) tahun yang disusun dengan berpedoman pada RPJPD dan RPJMN. Sedangkan RPJPD merupakan penjabaran dari visi, misi, arah kebijakan, dan sasaran pokok pembangunan daerah jangka panjang untuk 20 tahun yang disusun dengan berpedoman kepada RPJPN dan rencana tata ruang wilayah (RTRW).

Dari kaca mata perencanaan, ada 3 dokumen penting dan strategis dalam penyelenggaraan pemerintahan daerah yang merupakan satu kesatuan yang tidak dapat dipisahkan satu sama lain yang sering disebutdokumen 3 serangkai (three in one) yakni: RPJMD, RTRWP dan OPD. RPJMD merupakan kumpulan program kegiatan disertai pendanaan yang bersifat indikatif yang akan dilaksanakan dalam kurun waktu lima tahun mulai tahun pertama, kedua dan seterusnya, sesuai masa jabatan kepala daerah. Sedangkan dokumen RTRWP merupakan arahan lokasi dari seluruh rencana program kegiatan yang akan dilaksanakan sesuai periode perencanaan yakni 5 tahun sebagaimana tertuang dalam RPJMD. Adapun OPD adalah organisasi perangkat daerah yang akan merencanakan, melaksanakan, memonitor, mengevaluasi kedua dokumen perencanaan lainnya yakni RPJMD dan RTRWP.

RKPD merupakan penjabaran dari RPJMD yang memuat rencana kerangka ekonomi daerah, prioritas pembangunan daerah, serta rencana kerja dan pendanaan untuk jangka waktu I (satu) tahun yang disusun dengan berpedoman pada Rencana Kerja Pemerintah dan Program strategis nasional yang ditetapkan oleh Pemeritah Pusat'. Dengan demikian ada 5 dokumen RKPD yakni RKPD tahun I, tahun 2,tahun 3, tahun 4 dan tahun ke-5.

Rencana strategis (Renstra) Perangkat Daerah memuat tujuan, sasaran, program, dan kegiatan pembangunan dalam rangka Pelaksanaan Urusan Pemerintahan Wajib dan/ atau Urusan Pemerintahan Pilihan sesuai dengan tugas dan fungsi setiap Perangkat Daerah untuk periode 5 tahun, yang disusun berpedoman kepada RPJMD dan bersifat indikatif. Rencana kerja (Renja) Perangkat Daerah memuat program, kegiatan, lokasi, dan kelompok sasaran yang disertai indikator kinerja dan pendanaan sesuai dengan tugas dan fungsi setiap Perangkat Daerah untuk periode satu tahun, yang disusun berpedoman kepada Renstra Perangkat Daerah dan RKPD.

Rencana strategis (Renstra) eselon III adalah dokumen perencanaan unit eselon III yang merupakan penjabaran dari Renstra Perangkat Daerah yang memuat tujuan, sasaran, program, dan kegiatan pembangunan dalam rangka Pelaksanaan Urusan Pemerintahan Wajib dan/ atau Urusan Pemerintahan Pilihan sesuai dengan tugas dan fungsi setiap unit eselon III untuk periode 5 tahun, yang disusun berpedoman kepada Renstra Perangkat Daerah dan bersifat indikatif. Rencana kerja (Renja) Unit eselon III memuat program, kegiatan, lokasi, dan kelompok sasaran yang disertai indikator kinerja dan pendanaan sesuai dengan tugas dan fungsi setiap Unit Eselon III untuk periode satu tahun, yang disusun dengan berpedoman kepada Renstra Unit Eselon III yang bersangkutan dan Renja Perangkat Daerah. 
Seterusnya dokumen penganggaran terdiri dari KUA dan PPAS serta APBD. Kebijakan umum APBD disingkat KUA adalah dokumen yang memuat kebijakan bidang pendapatan, belanja dan pembiayaan serta asumsi yang mendasarinya untuk periode I (satu) tahun. Sedangkan prioritas dan plafon anggaran sementara yang selanjutnya disingkat PPAS adalah program prioritas dan patokan batas maksimal anggaran yang diberikan kepada Perangkat Daerah untuk setiap program sebagai acuan dalam penyusunan rencana kerja dan anggaran Satuan Kerja Perangkat Daerah(RKA SKPD). Selanjutnya anggaran pendapatan dan belanja daerah yang selanjutnya disingkat APBD adalah rencna keuangan tahunan daerah yang ditetapkan dengan Peraturan Daerah.

\subsubsection{Hubungan Pusat dan Daerah}

Pasal I UUD 1945 menyatakan bahwa Negara Indonesia adalah negara kesatuan berbentuk adalah republik. Konsekuensi logisnya adalah bahwa yang pertama kali dibentuk pemerintah nasional dan pemerintah nasional itulah yang membentuk pemerintahan daerah sesuai ketentuan peraturan perundang-undangan. Kemudian Pasal 18 ayat (2) dan ayat (5) UUD 1945 menyatakan bahwa pemerintahan daerah berwenang mengatur dan mengurus sendiri urusan pemerintahan menurut azas otonomi dan tugas pembantuan dan diberikan otonomi yang seluas-luasnya.

Pemberian otonomi seluas-luasnya kepada daerah diarahkan untuk mempercepat terwujudnya kesejahteraan masyarakat melalui peningkatan pelayanan, pemberdayaan dan peran serta masyarakat. Di samping itu melalui otonomi luasdalam lingkungan strategis global, daerah diharapkan mampu meningkatkan daya saing dengan memperhatikan prinsip demokrasi, pemerataan, keadilan, serta potensi dan keanekaragaman daerah dalam sistem NKRI. Pemberian otonomi yang seluas-luasnya kepada daerah dilaksanakan berdasarkan prinsip negara kesatuan. Dalam negara kesatuan kedaulatan hanya ada ditangan pemerintah nasional dan tidak ada kedaulatan pada daerah. Artinya seluas apapun otonomi yang diberikan kepada daerah tanggung jawab akhir penyelenggaraan pemerintahan daerah tetap berada di tangan pemerintah pusat. Untuk itu pemerintahan daerah pada sistem NKRI merupakan satu kesatuan dengan pemerintah nasional. Kebijakan yang dibuat dan dilaksanakan oleh pemerintahan daerah merupakan bagian integral dari kebijakan nasional.

Berdasarkan Pasal 19 Undang-Undang Nomor 23 Tahun 2014 Tentang Pemerintahan Daerah, urusan pemerintahan daerah wajib yang berkaitan dengan pelayanan dasar berjumlah 6 urusan. Sedangkan yang tidak berhubugan dengan pelayanan dasar berjumlah 18 urusan. Selanjutnya urusan pemerintahan pilihan berjumlah 8 urusan.

\subsection{Kerangka Konsepsi}

a. Rencana Pembangunan Jangka Panjang Daerah yang selanjutnya disingkat RPJPD adalah Dokumen Perencanaan Daerah untuk periode 20 (dua puluh) tahun.

b. Rencana Pembangunan Jangka Menengah Daerah yang selanjutnya disingkat RPJMD adalah Dokumen Perencanaan Daerah untuk periode 5 (lima) tahun terhitung sejak dilantik sampai dengan berahirnya masa jabatan Kepala Daerah.

c. Rencana Pembangunan Tahun Daerah yang selanjutnya disebut Rencana Kerja Pemerintah Daerah selanjutnya disingkat RKPD adalah Dokumen Perencanaan Daerah untuk periode I (satu) tahun. 
d. Rencana Strategis Perangkat Daerah yang selanjutnya disingkat dengan Renstra Perangkat Daerah adalah Dokumen Perencanaan Perangkat Daerah untuk periode 5 (lima) tahun.

e. Rencana Kerja Perangkat Daerah yang selanjutnya disingkat Renja Perangkat Daerah adalah Dokumen Perencanaan Perangkat Daerah untuk periode I (satu) tahun.

f. Anggaran Pendapatan dan Belanja Daerah yang selanjutnya disingkat APBD adalah rencna keuangan tahunan daerah yang ditetapkan dengan Peraturan Daerah.

g. Kebijakan Umum APBD yang selanjutnya disingkat KUA adalah dokumen yang memuat kebijakan bidang pendapatan, belanja dan pembiayaan serta asumsi yang mendasarinya untuk periode I (satu) tahun.

h. Prioritas dan Plafon Anggaran Sementara yang selanjutnya disingkat PPAS adalah program prioritas dan patokan batas maksimal anggaran yang diberikan kepada Perangkat Daerah untuk setiap program sebagai acuan dalam penyusunan rencana kerja dan anggaran Satuan Kerja Perangkat Daerah.

i. Permasalahan Pembangunan adalah kesenjangan antara kinerja pembangunan yang dicapai saat ini dengan yang direncanakan dan kesenjangan antara apa yang ingin dicapai dimasa datang dengan kondisi riil saat perencanaan dibuat.

j. Isu Strategis adalah kondisi atau hal yang harus diperhatikan atau dikedepankan dalam perencanaan pembangunan bagi Daerah dengan karakteristik bersifat penting, mendasar, mendesak, berjangka menengah/ panjang, dan menentukan pencapaian tujuan penyelenggaraan pemerintahan Daerah di masa yang akan datang.

k. Visi adalah rumusan umum mengenai keadaan yang diinginkan pada akhir periode perencanaan pembangunan Daerah.
I. Misi adalah rumusan umum mengenai upayaupaya yang akan dilaksanakan untuk mewujudkan visi.

m. Tujuan adalah sesuatu kondisi yang akan dicapai atau dihasilkan dalam jangka waktu 5 (lima) tahunan.

n. Sasaran adalah rumusan kondisi yang menggambarkan tercapainya tujuan, berupa hasil pembangunan Daerah/Perangkat Daerah yang diperoleh dari pencapaian hasil (outcome) program Perangkat Daerah.

o. Strategi adalah langkah berisikan programprogram sebagai prioritas pembangunan Daerah/Perangkat Daerah untuk mencapai sasaran.

\section{ANALISIS}

\section{I.Pengaturan Penyusunan Proper}

\section{Diklatpim Bagi Pejabat Pemerintahan} Daerah Provinsi Saat Ini

Guna mewujudkan pejabat ASN dengan kompetensi sebagaimana disebutkan di atas, diperlukan penyelenggaraan diklatpim tingkat III yanginovatif, yaitu diklat yang memungkinkan peserta mampu menerapkan kompetensi yang telah dimilikinya. Dalam penyelenggaraan Diklatpim Tingkat III seperti ini, peserta dituntut untuk menunjukkan kinerjanya dalam merancang suatu perubahan yang terkait dengan arah kebijakan sektor, wilayah, dan isu strategis nasional, serta daerah/wilayah dan sekaligus memimpin perubahan tersebut hingga menimbulkan hasil yang signifikan. Kemampuan memimpin perubahan inilah yang kemudian menjadi tolok ukur dalam menentukan keberhasilan peserta tersebut dalam penyelenggaraan Diklatpim Tingkat III. Dengan demikian, Diklatpim Tingkat III diharapkan dapat menghasilkan alumni yang tidak hanyamemiliki kompetensi, tetapi sekaligus juga mampu 
menunjukkan kinerjanyadalam memimpin perubahan.

Dalam Perkalan Nomor 19 Tahun 2015 tersebut juga ditegaskan bahwa kompetensi yang dibangun pada Diklatpim Tingkat III adalah kompetensi kepemimpinan visioner yaitu kemampuan berkolaborasi dengan pemangku kepentingan strategis untuk menangani isu nasional strategis, dan memimpin peningkatan kinerja instansinya melalui penetapan visi atau arah kebijakan yang tepat, yang diindikasikan dengan kemampuan antara lain:

a. melakukan kolaborasi secara internal dan eksternal dalam mengelola tugas-tugas organisasi ke arah pencapaian tujuan pembangunan nasional dan visi instansinya;

b. melakukan inovasi sesuai bidang tugasnya guna penetapan arah kebijakan yang lebih efektif dan efisien; dan sebagainya.

Untuk mampu mencapai kompetensi seperti diutarakan di atas, dalam Perkalan dimaksud telah disusun struktur kurikulum Diklatpim Tingkat 3 yang terdiri dari 5 (lima) agenda pembelajaran yakni: penguasaan diri (self mastery), diagnosa perubahan (diagnostic reading), inovasi, tim efektif dan proyek perubahan. Adapun tahapan pembelajaran berikut agenda dan mata diklatnya sebagai berikut:

I. Tahap Diagnosa Kebutuhan Perubahan.

Pada tahap ini peserta diarahkan untuk menentukan area perubahan pada program yang berkaitan dengan tugas dan fungsi unit peserta. Tahap ini terdiri dari 4 agenda pembelajaran dengan sejumlah mata diklat yakni:

a. Agenda inovasi dengan mata diklat Inovasi khususnya materi Konsepsi Inovasi.

b. Agenda penguasaan diri dengan mata Diklat Wawasan Kebangsaan dan Integritas. c. Agenda Pembelajaran Diagnosa Perubahan yang terdiri dari mata Diklat: Isu Strategis dan Diagnostic Reading.

d. Agenda Proyek Perubahan terdiri dari mata Diklat: Proyek Perubahan khususnya materi Konsepsi Proyek Perubahan dan Pembimbingan (coaching).

Produk pembelajaran pada tahap ini adalah identifikasi individu terhadap program yang berkaitan dengan tugas dan fungsi unit yang bermasalah.

2. Tahap Membangun Komitmen Bersama.

Pada tahap ini peserta diarahkan untuk membangun komitmen bersama dengan sejumlah pemangku kepentingan untuk melaksanakan perubahan terkait dengan program yang berhubungan dengan tugas dan fungsi unit. Agenda pembelajaran dalam tahap ini adalah Proyek Perubahan dengan mata Diklat Pembimbingan (coaching dan mentoring) dan konseling.Produk pembelajaran dalam tahap ini adalah komitmen bersama dengan pemangku untuk melakukan perubahan pada program yang berkaitan dengan tugas dan fungsi unit yang bermasalah.

3. Tahap Merancang Perubahan dan Membangun Tim.

Pada tahap ini peserta diarahkan untuk menyusun rancangan Proyek Perubahan yang inovatif dan cara membangun tim yang efektif untuk melaksanakan perubahan terkait dengan program yang berhbnga tugas dan fungsi unit. Tahap ini terdiri dari 3 agenda pembelajaran dengan uraian mata Diklat sebagai berikut:

a. Agenda Inovasi dengan mata Diklat Inovasi: strategi inovasi, budaya kerja dalam efektifitas kepemimpinan dan Benchmarking ke Best Practise.

b. Agenda Tim Efektif dengan mata Diklat: Membangun Tim Efektif dan Jejaring Kerja. 
c. Agenda Proyek Perubahan dengan mata Diklat: Merancang Proyek Perubahan, Presentasi Rancangan Proyek Perubahan, dan Implementasi Proyek Perubahan.

Produk pembelajaran dalam tahap ini adalah rancangan proyek perubahan dan pemetaan potensi pemangku kepentingan terkait untuk melakukan perubahan pada pada program yang berkaitan dengan tugas dan fungsi unit.

4. Tahap Laboratorium Kepemimpinan.

Pada tahap ini peserta diarahkan untuk mengimplementasikan proyek sesuai dengan program yang berhubungan tugas dan fungsi unit yang melibatkan pemangku kepentingan sesuai dengan milestone yang disusun. Agenda pembelajaran dalam tahap ini adalah proyek perubahan dengan mata Diklat Pembimbingan (coaching dan mentoring) dan Konseling.

Produk pembelajaran dalam tahap ini adalah Implementasi Proyek Perubahan sesuai dengan program yang berhubungan dengan tugas dan fungsi unit. Implementasi Proyek Perubahan berdasarkan milestone dengan melibatkan pemangku kepentingan disertai dengan bukti-bukti berupa notulen/transkrip tertulis/audio/visual, foto, daftar hadir, dan sebagainya.

5. Tahap evaluasi

Tahap pembelajaran ini mengarahkan peserta untuk menyajikan Proyek Perubahan yang dihasilkan sesuai dengan milestone disertai dengan bukti-bukti berupa notulen/transkrip tertulis/audio/visual, foto, daftar hadir, dan sebagainya. Agenda pembelajaran dalam tahap ini adalah Proyek Perubahan dengan mata Diklat sebagai berikut:
a. Pembimbingan;
b. Evaluasi laboratorium kepemimpinan; dan
c. Evaluasi Kepemimpinan Peserta

Produk pembelajaran dalam tahap ini adalah implementasi sesuai dengan program yang berkaitan dengan tugas dan fungsi unit berdasarkan milestone serta sudah dievaluasi dan didesiminasikan kepada peserta lain.

\subsection{Implementasi Penyusunan Proyek Perubahan Diklatpim Bagi Pejabat Pemerintah Daerah Provinsi}

a. Jadwal pelaksanaan diklatpim dan agenda penyusunan dokumen perencanaan dan penganggaran (PP) pada penyelenggaraan pemerintahan daerah

I). Jadwal pelaksanaan diklatpim disusun sesuai kebutuhan berdasarkan perencanaan yang dibuat oleh Badan Pengembangan Sumber Daya Manusia (BPSDM) Provinsi Kalimantan Tengah. Untuk tahun 2018 jadwal diklatpim baik tingkat III maupun tingkat IV telah disusun dimana diklatpim III terdiri dari 4 angkatan yakni angkatan XIII dan XIV dari tanggal 22 Maret sampai dengan 29 Juni 2018, dan angkatan XV dan XVI dari tanggal 14 September sampai dengan I5 Desember 2018. Sedangkan untuk diklatpim IV meliputi 7 angkatan yang dilaksanakan dari tanggal 22 Maret s.d Desember 2018.

2). Agenda Penyusunan Dokumen Perencanaan dan Penganggaran (PP) Pemerintahan Daerah Provinsi

Memgingat penting dan strategisnya dokumen prencanaan dan penggaran (PP) dan umumnya selama ini Pemerintahan Daerah baik provinsi maupun kabupaten/kota sering mengalami keterlambatan dalam Penetapan dan pengesahannya yang berakibat pada terlambatnya agenda pembangunan dan tidak tercapainya targettarget indikator kinerja sesuai amanat RPJMD, maka telah diatur jadwal mulai dari penyusunan, 
pembahasan dan pengesahan berbagai dokumen PP dimaksud. Pengaturan tersebut tertuang dalam berbagai peraturan perundang-undangan antara lain: UU Nomor 25 Tahun 2004Tentang SPPN, UU Nomor 23 Tahun 2014 Tentang Pemerintahan Daerah, UU Nomor 17 Tahun 2003Tentang Keuangan Negara, Undang-Undang Nomor I Tahun 2004 Tentang Perbendaharaan Negara, Peraturan Pemerintah (PP) Nomor 58 Tahun 2005 Tentang Keuangan Daerah, Permendagri RI Nomor 86 Tahun 2017 dan lain sebagainya. Dalam pengaturan tersebut juga ditegaskan sanksi bagi pihak yang gagal melaksanakan tugasnya yang menyebabkan gagal dan terlambatnya penetapan dokumen PP.

Berikut disampaikan arahan jadwal penyusunan dan pengesahan/penetapan berbagai dokumen PP pada penyelenggaraan pemerintahan daerah berikut sanksinya.

Peraturan daerah (Perda) Tentang RPJPD dan Perda Tentang RPJMD harus disusun dan ditetapkan masing-masing paling lambat 6 bulan setelah kepala daerah dilantik dan apabila terlambat akan dikenakan sanksi administratif berupa tidak dibayarkan hak-hak keuangan masing-masing selama 3 bulan. Sedangkan apabila kepala daerah tidak menetapkan Perkada tentang RKPD untuk Tahun $\mathrm{N}$ paling lambat Tanggal 3 I Mei Tahun $\mathrm{N}-\mathrm{I}$, akan dikenai sanksi berupa tidak dibayarkannya hak-hak keuangan selama 3 bulan.

Selain itu juga telah diatur jadwal penyusunan APBD mulai dari penyusunan Raperda sampai dengan pengesahan Perda APBD. Kepala Daerah wajib mengajukan Raperda tentang APBD disertai dokumen pendukungnya paling lambat minggu pertama Oktober tahun berjalan. Bagi kepala daerah yang tidak mengajukan Raperda dimaksud secara tepat waktu dikenai sanksi administratif berupa tidak dibayarkan hak-hak keuangan selama 6 bulan. Sedangkan apabila Kepala Daerah dan DPRD tidak menyetujui bersama Raperda tentang APBD paling lambat tanggal 30 November tahun berjalan akan dikenai sanksi administratif berupa tidak dibayarkan hak-hak keuangan selama 6 bulan

PD menyusun Renstra berpedoman kepada RPJMD yang memuat tujuan, sasaran, program dan kegiatan pembangunan dalam rangka pelaksanaan urusan wajib dan atau urusan pemerintahan pilihan sesuai tupoksi PD. Pencapaian sasaran, program, dan kegiatan pembangunan dalam Renstra PD dilaksanakan dengan pencapaian sasaran, program, dan kegiatan pembangunan yang ditetapkan dalam Renstra Kementerian/Lembaga. Renstra PD ditetapkan dengan Perkada setelah RPJMD ditetapkan. Renstra PD dirumuskan ke dalam rencana kerja PD dan digunakan sebagai bahan penyusunan RKPD. Renstra PD memuat program, kegiatan, lokasi, dan kelompok sasaran yang disertai indikator kinerja dan pendanaan sesuai dengan tupoksi setiap PD. Renstra PD ditetapkan dengan Perkada setelah RKPD ditetapkan.

RKPD untuk tahun $\mathrm{N}$ harus ditetapkan dengan Peraturan Kepala Daerah (Perkada) paling lambat tanggal 3 I Mei tahun N-I. Demikian pula KUA dan PPAS tahun $\mathrm{N}$ harus disepakati oleh Kepala Daerah dan Pimpinan DPRD melalui Nota Kesepakatan Bersama paling lambat tanggal 31 Juli tahun $\mathrm{N}-\mathrm{I}$. Maknanya adalah bahwa paling lambat tanggal 3I Juli tahun $\mathrm{N}$-I seluruh program dan kegiatan yang akan dilaksanakan pada tahun $\mathrm{N}$ harus diakomodir di internal Pemerintah Provinsi dan disepakati oleh Kepala Daerah dan Pimpinan DPRD. 
Mencermati jadwal Pemerintah Provinsi Kalimantan Tengah tentang pelaksanaan diklatpim tahun 2018 seperti diuraikan di atas, dapat dijelaskan bahwa mengingat RKPD Tahun 2019 sudah ditetapkan pada Tanggal 3 I Mei 2018 maka seluruh proyek perubahan yang dihasilkan oleh semua angkatan diklatpim tingkat III dan tingkat IV tidak dapat diakomodir pada dokumen PP tahun 2019. Sesuai ketentuan, seluruh rencana kegiatan termasuk proper yang akan dilaksanakan pada tahun 2019 di pemerintahan daerah harus sudah dibahas pada musrenbang RKPD yang dilaksanakan pada sekitar bulan Maret-April 2018 serta kegiatan dimaksud harus sudah disepakati oleh TAPD paling lambat pada 3I Mei 2018 pada saat ditetapkannya RKPD 2019 melalui Peraturan Gubernur. Dengan demikian seluruh proper hasil diklatpim tahun 2018 paling cepat bisa diimplementasikan pada tahun 2020.

b. Adanya time leg antara pelaksanaan diklatpim dengan implementasi proper di instansi

Mengingat adanya jeda waktutime leg yang cukup lama antara pelaksanaan diklatpim dan implementasi proper maka akan timbul beberapa permsalahan anatara lain:

I) Pergeseran isu strategis

Penulis berharap seluruh pejabat eselon III dan pejabat eselon IV telah menyusun renstra masing-masing. Dengan demikian isu strategis yang dipilih untuk ditangani pada proper dalam pelaksanaan diklatpim Tahun $\mathrm{N}$ harus memilih isu strategis pada Tahun $\mathrm{N}+2$, dan ini tentunya sangat menyulitkan baik peserta maupun widyaiswara selaku coach dan penyelenggara.

2) Mutasi pejabat

Mengingat adanya time leg yang cukup lama maka peluang untuk terjadinya mutasi pejabat sangat tinggi sehingga proper dikhawatirkan tidak akan terimplementasi. Namun demikian apabila issu strategis yang ditangani merupakan permasalahan riel PD dan Daerah, maka Penulis yakin proper ini akan tetap terlaksana dengan baik siapapun pejabatnya.

a. Penetapan isu-isu strategis daerah/PD

Isu strategis daerah harus dapat menggambarkan dinamika lingkungan ekternal, baik skala regional, nasional maupuninternasional yang berpotensi memberi dampak terhadap daerah dalam kurun waktu jangka menengah maupun jangka panjang.

Penentuan isu strategis daerah ditentukan dengan dokumen yang disusun yakni jangka panjang (20 tahun), jangka menengah (5 tahun) dan jangka pendek (I tahun). Sebagai gambaran/rujukan umum dalam menganalisis guna menentukan prioritas isu-isu strategis daerah/PD dari beberapa isu strategis yang diusulkan dari berbagai pihak dapat dilakukan sebagaimana disajikan berikut ini.

Sebagai referensi, dibawah ini disajikan kriteria dan penentuan isu-isu strategis daerah/PD dengan diberi bobot antara 0 I00\%.Beberapa contoh kriteria dan penentuan isu strategis adalah:

I) Kegiatan/program tersebut Memiliki pengaruh yang besar/signifikan terhadap pencapaian sasaran pembangunan nasional/daerah/PD dengan bobot $20 \%$;

2) Merupakan wewenang, tugas dan tanggung jawab daerah/PD dengan bobot $20 \%$;

3) Magnitudo dampak yang ditimbulkannya terhadap daerah/PD dan masyarakat dengan bobot 10\%;

4) Memiliki daya ungkit yang signifikan terhadap sasaran pembangunan daerah/PD dengan bobot $10 \%$;

5) Tingkat kesulitan/kemudahan untuk ditangani dengan bobot 15\%;

6) Janji politik kepala daerah untuk ditangani dengan bobot $25 \%$,dst 
Beberapa permasalahan penetapan isu strategis daerah dalam proper antara lain adalah adanya time leg yang cukup jauh antara pelaksanaan diklatpim dengan pendanaan sebagaimana diuraikan di atas. Umumnya peserta merupakan pejabat eselon III, eselon IV atau staf senior, sehingga tidak memiliki renstra karena memang tidak dipersyaratkan oleh peraturan yang berlaku.

b. Pembentukan Perangkat Daerah Kaitannya dengan Dokumen PP

Pembentukan perangkat daerah (PD) didasarkan pada prinsip tepat fungsi dan tepat ukuran (rightsizing) berdasarkan beban kerja yang sesuai dengan kondisi nyata di masingmasing daerah. Di samping itu penataan PD juga dilakukan secara rasional, proporsional, efektif dan efisien. Dinas daerah merupakan pelaksana fungsi inti yang melaksanakan tugas dan fungsi sebagai pembantu kepala daerah dalam melaksanakan fungsi mengatur dan mengurus sesuai bidang urusan pemerintahan yang diserahkan kepada daerah baik urusan wajib maupun urusan pilihan. Namun pada kenyataannya pembentukan PD jauh menyimpang dari ketentuan tersebut. Seperti diuraikan di atas ada beberapa PD tidak mengacu pada prinsip-prinsip di atas. Sebagai contoh adalah Dinas Kependudukan dan Pencatatan Sipil Provinsi. Berdasarkan Lampiran UU Nomor 23 Tahun 2014 Tentang Pemerintahan Daerah, Pembagian Urusan Pemerintahan Konkuren Antara Pemerintah Pusat dan Daerah Provinsi dan Daerah Kabupaten/Kota, Bagian I.L Pembagian Urusan Pemeerintahan Bidang Administrasi Kependudukan dan Pencatatan Sipil ditegaskan bahwa satu-satunya kewenangan Pemerintah Provinsi adalah Sub Urusan Profile Kependudukan yakni penyusunan profile kependudukan provinsi.Bagaimana mungkin pemerintah membentuk suatu instansi setingkat eselon IIA padahal tupoksi dan kewenangannya hanya untuk menangani empat kata. Penulis dapat memahami bahwa Disdukcapil provinsi pasti mengalami kesulitan menyusun renstra PD mengingat tugasnya yang sangat dangkal. Demikian pula pejabat eselon III dan eselon IV juga pasti mengalami kesulitan dalam menyusun renstra eselon III dan renstra eselon IV. Dengan kondisi ini jelas terlihat bahwa pembentukan disdukcapil provinsi terkesan sangat dipaksakan setingkat eselon IIA dan tidak memenuhi prinsip-prinsip right sizing, efektif dan efisien sesuai dengan beban tugas. Hal lain yang juga menjadi permasalahan adalah penempatan fungsi tata ruang dan fungsi statistik yang sebelum era PP Nomor 18 Tahun 2016 berada di Bappeda namun setelah PP Perangkat Daerah tersebut fungsi statistik berada di Diskominfo sedangkan fungsi tata ruang berada di Dinas Pekerjaan Umum dan Penataan Ruang. Seperti diketahui Bappeda yang menangani perencanaan dan pengendalian identik dengan data sehingga pengelolaan statistik seyogianya tetap berada di Bappeda. Demikian pula dengan fungsi tata ruang, mengingat tata ruang merupakan dokumen perencanaan maka seyogianya fungsi tersebut melekat di Bappeda. Disamping itu Dinas PUPR merupakan unsur pengguna ruang maka PUPR seolah-olah berfungsi ganda yakni pengguna dan perencana sehingga terjadi semacam conflict of interest.

\subsection{Pengaturan Penyusunan Proper} Diklatpim Bagi Pejabat Pemerintahan Daerah Provinsi Ke Depan

Paling tidak ada empat kondisi disharmoni yang terjadi dalam penyelenggaraaan pelaksanaan diklatpim yang menyebabkan 
kurang efektifnya pelaksanaan diklatpim yakni: jadwal pelaksanaan diklatpim khususnya proyek perubahan yang tidak mengacu dan bersinerji dengan jadwal penyusunan dan penetapan dokumen perencanaan dan penganggaran, adanya time leg antara pelaksanaan diklatpim dengan implementasi proper di instansi, kurang tepatnya penetapan isu-isu strategs daerah/PD, kurang tepatnya (right sizing) yang menyebabkan kurang paripurnanya hasil diklatpim khususnya kualitas proper dan implementasinya yang tidak terlaksana dengan baik. Sehubungan dengan hal tersebut ke depan perlu dilakukan hal-hal sebagai berikut:

a. Sinkronisasi dan sinergitas jadwal pelaksanaan diklatpim dengan jadwal penyusunan dan penetapan dokumen PP, termasuk implementasi proper di instansi. Dengan demikian tidak ada lagi time leg dan kalaupun ada tetapi tidak terlalu lama

b. Pemilihan dan penetapan isu-isu strategis

Pemilihan dan penetapan isu-isu strategis dalam proper tentunya sangat erat kaitannya dengan waktu. Isu-isustrategis dipilih dan ditetapkan sesuai arahan RPJMD yang telah dijabarkan ke dalam renstra PD terkait. Seterusnya renstra PD tersebut juga telah diterjemahkan ke dalam renstra bidang terkait di PD yang bersangkutan. Apabila pelaksanaan proyek perubahan mengalami keterlambatan dalam implementasinya tentu diperlukan justifikasi berupa penyesuaian agar issu-issu yang diangkat masih relevan untuk diimplementasikan sehingga tetap berdaya dan berhasil guna serta bermanfaat bagi para pemangku kepentingan

c. Pembentukan PD dan Penempatan fungsifungsi tertentu secara kurang tepat serta sekuens pelaksanaan program dan kegiatan
Seperti diuraikan di atas, banyak PD dibentuk secara tidak tepat dan tidak mengacu kepada kaidah-kaidah organisasi dan manajemen. Salah satu contoh dinas yang tidak tepat ditinjau dari sisi beban tugas adalah Dinas Kependudukan dan Pencatatan Sipil (disdukcapil) Provinsi. Sesuai UU PD, satu-satunya sub urusan yang menjadi kewenangan pemerintah provinsi dalam bidang administrasi kependudukan dan pencatatan sipil adalah sub urusan profil kependudukan yakni penyusunan profil kependudukan provinsi. Pembentukan Disdukcapil provinsi setingkat eselon IIA merupakan pemborosan sumber daya mengingat beban tugasnya sangat sedikit. Penulis mengusulkan agar dinas tersebut cukup setingkat eselon IIIA di bawah Biro Pemerintahan atau di bawah Dinas Pemberdayaan Perempuan Anak, KB, dan Kependudukan. Demikian pula halnya dengan fungsi statistik yang selama ini berada di Bappeda karena memang perencanaan sangat identik dengan data, namun setelah terbitnya PP Nomor 18 Tahun 2016, fungsi statistik berada di lingkup Diskominfo. Kondisi seperti ini menyebabkan perencanaan yang dibuat tidak sepenuhnya benar bahkan terkesan dipaksakan. Terkait dengan fungsi tata ruang, Penulis juga menyarankan untuk digabung dengan Bappeda seperti sebelumnya.

\section{KESIMPULAN DAN SARAN}

\section{I Kesimpulan}

a. Pengaturan penyusunan proper

Secara umum pengaturan
penyelenggaraan diklatpim tingkat III dan tingkat IV diatur dengan Perkalan masing-masing Nomor 19 Tahun 2015 dan Nomor 20 Tahun 2015. Kompetensi yang dibangun melalui diklatpim ini adalah kemampuan untuk 
membuat perubahan pada instansi yang bersangkutan sekaligus juga kemampuan untuk meminpin pelaksanaan perubahan dimaksud. Dengan demikian maka roh/inti dari diklatpim adalah proyek perubahan (proper).

b. Implementasi penyusunan proper Sesuai ketentuan perundang-undangan yang berlaku telah ada agenda penyusunan dan penetapan/pengesahan dokumen PP, dimana RKPD tahun $\mathrm{N}$ harus ditetapkan pada tanggal 3I Mei Tahun N-I. Demikian pula PPAS harus ditetapkan secara bersama-sama antara kepala daerah dengan DPRD pada tanggal 31 Juli Tahun N-I. Di lain pihak diklatpim yang menghasilkan proper dilaksanakan tanpa bersinerji dengan jadwal waktu penyusunan dan penetapan dokumen PP yang mengharuskan adanya time leg (jeda waktu) paling tidak 2 tahun. Jeda waktu ini berakibat pada bergesernya isu strategis daerah/PD dan kemungkinan terjadinya mutasi pejabat. Hal lain yang menjadi permasalahan dalam pelaksanaan diklatpim khususnya dalam penyusunan proper adalah pembentukan perangkat daerah yang tidak didasarkan pada prinsip-prinsip rightsizing, efektif dan efisien sesuai beban kerja. Disdukcapil, Dinas PUPR, Diskominfo adalah beberapa contoh yang tidak memenuhi kaidahkaidah tersebut. Akibat hal tersebut maka proper tidak terlaksana dengan baik sesuai maksud Perkalan dimaksud. Untuk itu perlu dilakukan pengkajian terhadap berbagai hal mulai dari perencanaan, substansi proper dan evaluasinya.

c. Pengaturan penyusunan proper ke depan

Mengacu pada uraian tersebut di atas maka dalam pelaksanaan diklatpim bagi pejabat pemerintah daerah provinsi perlu dilakukan:

I) Jadwal pelaksanaan diklatpim harus bersinerji dengan agenda penyusunan dokumen PP pemerintah provinsi sehingga tidak ada time leg dan kalaupun ada tetapi tidak terlalu lama;

2) Masing-masing pejabat eselon III dan eselon IV diwajibkan membuat dan membawa renstra eselon III dan renstra eselon IV yang mengacu kepada RPJMD dan atau Renstra PD. Isu strategis harus ditetapkan dari renstra terkait;

3) Harus ada jaminan dari TAPD bahwa proper yang dihasilkan oleh diklatpim akan diakomodir pada dokumen PP dan akan diimplementasikan pada saatnya ;

4). Perlu dilakukan audit menyeluruh terhadap PD untuk memastikan semua PD yang dibentuk sesuai dengan prinsip-prinsip sebagaimana diatur daalam PP Nomor 18 Tahun 2016 Tentang Perangkat Daerah;

5).Evaluasi paska diklat dilakukan untuk mengetahui tentang implementasi proper terutama kinerja capaiannya;

\subsection{Saran/Rekomendasi}

a. Perlu dibuat rakor tentang penyamaan persepsi antara LAN, Kemendagri dan Pemerintah Provinsi terkait dengan penyelenggaraan diklatpim yang bersinerji dengan agenda penyelenggaraan pemerintahan daerah provinsi

b. Mengingat ruh/inti dari diklatpim adalah penyusunan dan implementasi proper maka para pihak harus bersinerji untuk menghasilkan proper yang paripurna. Mengingat peran coach, mentor, penguji dan penyelenggara sangat strategis, maka para pihak harus diberikan pemahaman yang paripurna tentang penulisan proper;

c. Kiranya perangkat aturan dalam penyelenggaraan diklatpim perlu disesuaikan untuk mencapai hasil yang paripurna; 
d. Penunjukan peserta dapat dilakukan sedemikian rupa sehingga yang bersangkutan dapat mempersiapkan proper secara paripurna;

\section{DAFTAR PUSTAKA}

Agus Dwiyanto, dkk. 2012. Reformasi Birokrasi Publik di Indonesia. Yogyakarta: Gajahmada University Press.

Juniarso, R., dan A. Sidik, 2017. Hukum Administrasi Negara dan Kebijakan Pelayanan Publik, Bandung: Penerbit Nuansa Cendekia,

Nasution, A.H. dan Kartajaya, 2018. Inovasi, Yogyakarta: Andi,

Osborne, D. Dan Gaebler, T. 1996. Mewirausahakan Birokrasi. Jakarta: PT. Pustaka Birman Presindo

Osborne, D. Dan Plastrik P. T, 2000. Memangkas Birokrasi Wirausaha. Jakarta: Penerbit PPM

Silalahi, U., dan Wirman S., 2015. Desentralisasi dan Demokrasi Pelayanan Publik Menuju Pelayanan Pemerintah Daerah lebih Transparan, Partisipatif, Responsif dan Akuntabel. Sumedang:IPDN Press,

Sinamo, N. 2015 Hukum Administrasi Negara Suatu Kajian Kritis Tetang Birokrasi Negara Jakarta: Jala Permata Aksara

Sirajuddin, dkk 2016 Hukum Administrasi Pemerintahan Daerah Sejarah, Asas, Kewenangan, dan Pengawasan Penyelenggaraan Pemerintahan Daerah Malang: Setara Press

Wasistiono,S. dan Polyando,P. 2017. Politik Desentralisasi di Indonesia. Jatinangor, Bandung: IPDN Press
Republik Indonesia. 2003. Undang-Undang Republik Indonesia Nomor 17 Tahun 2003 Tentang Keuangan Negara. Jakarta: Sekretariat Negara.

Republik Indonesia. 2004. Undang-Undang Republik Indonesia Nomor 25 Tahun 2004 Tentang Sistem Perencanaan Pembangunan Nasional. Jakarta: Sekretariat Negara.

Republik Indonesia. 2007. Undang-Undang Republik Indonesia Nomor 17 Tahun 2007 Tentang RPJP Nasional Periode Tahun 2005-2025. Jakarta: Sekretariat Negara Republik Indonesia.

Republik Indonesia. 2009 Undang-Undang RI Nomor 25 Tahun 2009 Tentang Pelayanan Publik, Jakarta: Sekretariat Negara

Republik Indonesia. 2014 Undang-Undang RI Nomor 5 Tahun 2014 Tentang Aparatur Sipil Negara, Jakarta: Sekertaris Negara.

Republik Indonesia. 2016. Undang-Undang Nomor 23 Tahun 2014 Tentang Pemerintahan Daerah dan Perubahannya. Jakarta: Sekretariat Negara.

Peraturan Pemeritah RI Nomor II Tahun 2017 Tentang Manajemen Pegawai Negeri Sipil.

Permendagri Nomor 86 Tahun 2017 Tentang Tata

Cara Perencanaan, Pengendalian dan Evaluasi Pembangunan Daerah, Tata Cara Evaluasi Rancangan Peraturan Daerah Tentang RPJPD dan RPJMD Serta Tata Cara Perubahan RPJPD, RPJMD dan RKPD

Perkalan Nomor 19 Tahun 2015 Tentang Pedoman Penyelenggaraan Pendidikan dan Pelatihan Kepemimpinan Tingkat III

Perkalan Nomor 20 Tahun 2015 Tentang Pedoman Penyelenggaraan Pendidikan dan Pelatihan Kepemimpinan Tingkat IV 